\title{
PENGARUH MODEL PEMBELAJARAN KOOPERATIF NUMBERED HEAD TOGETHER TERHADAP HASIL BELAJAR MATEMATIKA SISWA KELAS V SD
}

\author{
Ahmad Na'im ${ }^{1}$, Wuli Oktiningrum ${ }^{2}$ \\ Universitas Islam Raden Rahmat Malang ${ }^{1,2}$ \\ ahmadnaim811@gmail.com ${ }^{1}$ \\ wulie.okti@gmail.com²
}

\begin{abstract}
ABSTRAK
Penelitian ini bertujuan untuk mengetahui pengaruh model pembelajaran Numbered Head Together (NHT) terhadap hasil belajar matematika siswa kelas V SD Negeri 2 Sumberejo Kabupaten Malang. Jenis penelitian ini adalah penelitian kuantitatif quasi eksperimental dengan desain Nonequivalent Control Group Design. Sampel penelitian adalah 20 siswa kelas eksperimen yang menggunakan model pembelajaran NHT dan 20 siswa kelas kontrol yang menggunakan model pembelajaran konvensional. Teknik pengambilan data menggunakan tes dan angket. Hasil uji Independent Sample t Test menunjukkan bahwa $t_{\text {hitung }}$ lebih besar dari $t_{a b e l}$. Jadi disimpulkan bahwa terdapat pengaruh signifikan model pembelajaran kooperatif Numbered Head Together (NHT) terhadap hasil belajar matematika siswa kelas V SD. Pengaruh tersebut terlihat pada selisih nilai rata-rata kedua kelas, dimana kelas kontrol memiliki nilai rata-rata 53,6 sedangkan kelas eksperimen memiliki nilai rata-rata 63,8. Hasil angket juga menunjukkan bahwa siswa setuju terhadap penerapan model pembelajaran Numbered Head Together (NHT) di kelas mereka.
\end{abstract}

Kata kunci : NHT, hasil belajar, siswa sekolah dasar

\begin{abstract}
This study aims to determine the effect of the Numbered Head Together (NHT) learning model on mathematics learning outcomes for fifth grade students of SD Negeri 2 Sumberejo, Malang Regency. This type of research is a quasiexperimental quantitative research with Nonequivalent Control Group Design. The research sample was 20 experimental class students who used the NHT learning model and 20 control class students who used conventional learning models. Data collection techniques using tests and questionnaires. Independent Sample t Test results show that the t-count is greater than the table. So it was concluded that there was a significant effect of the Numbered Head Together (NHT) cooperative learning model on the mathematics learning outcomes of fifth grade elementary school students. The influence is seen in the difference in the average value of the two classes, where the control class has an average value of 53.6 while the experimental class has an average value of 63.8 . The results of the questionnaire also showed that students agreed to the application of the Numbered Head Together (NHT) learning model in their classrooms.
\end{abstract}

Keywords : NHT, learning outcomes, elementary school students 


\section{PENDAHULUAN}

Rendahnya hasil belajar siswa SD menjadi permasalahan umum yang terjadi di sekolah-sekolah SD. Hal ini dipengaruhi oleh berbagai faktor. Salah satu faktor yang memengaruhi rendahnya hasil belajar siswa adalah model pembelajaran yang digunakan oleh guru dalam proses pembelajaran. Hasil penelitian Ruliani dan Pramukantoro (2014:141) menunjukkan bahwa jenis model pembelajaran yang digunakan oleh guru dalam pembelajaran berpengaruh terhadap hasil belajar siswa. Sama halnya dengan Awang (Awang, dkk., 2017:1) dalam penelitiannya menjelaskan bahwa model pembelajaran juga mempengaruhi hasil belajar, namun pengaruhnya tidak signifikan karena setiap model pembelajaran memiliki kelebihan dan kelemahan.

Hasil observasi langsung pada siswa kelas V SDN 2 Sumberejo Kecamatan Gedangan menunjukkan bahwa model pembelajaran yang digunakan dalam pembelajaran matematika adalah model pembelajaran tutor teman sebaya. Penerapan model pembelajaran tersebut mengalami beberapa hambatan, antara lain: masih banyak nilai matematika siswa yang belum memenuhi nilai Kriteria Ketuntasan Minimal (KKM), kurangnya sikap aktif siswa dalam pembelajaran matematika, siswa menganggap mata pelajaran matematika sebagai mata pelajaran yang sulit untuk dipahami, dan siswa kurang menghargai pendapat teman ketika mengerjakan tugas kelompok. Siswa dengan kemampuan belajar tinggi juga acuh dengan teman sekelas yang mengalami kesulitan belajar matematika. Keterampilan sosial siswa tergolong rendah, karena mereka yang masuk dalam kelompok pintar enggan membagi ilmunya dengan teman-temannya yang kurang pintar. Munculnya fenomena tersebut, menyebabkan permasalahan di kelas yang berdampak negatif pada proses dan hasil belajar matematika kelas V SDN 2 Sumberejo Kecamatan Gedangan. Permasalahan proses dan hasil belajar siswa tersebut perlu diperhatikan oleh guru, mengingat kurikulum 2013 menuntut siswa agar siswa berpartisipasi aktif dalam menemukan konsep serta menyampaikan ide-ide dalam menentukan jawaban dengan tepat, sehingga pembelajaran berlangsung secara inspiratif, menyenangkan, menantang, serta memotivasi peserta didik untuk berpartisipasi aktif dalam pembelajaran (Peraturan Pemerintah No. 19 Tahun 2005).

Meninjau permasalahan dalam pembelajaran matematika tersebut, maka diperlukan model pembelajaran kooperatif yang inovatif dan menyenangkan, salah satunya menggunakan model pembelajaran kooperatif dengan tipe Numbered Head Together (NHT). Pembelajaran kooperatif Numbered Head Together adalah model pembelajaran yang dikembangkan oleh Spencer Kagan (Gustadevi, Ngadiso, dan Asib, 2012:194). Model pembelajaran ini merupakan model pembelajaran yang lebih banyak melibatkan siswa dalam menelaah materi yang tercakup dalam satu pelajaran dan mengecek pemahaman siswa terhadap isi pelajaran (Nurhadi, dkk, 2004:67). Kagan (Santiana, dkk, 2014:3) menjelaskan bahwa tujuan diterapkannya model pembelajaran kooperatif Numbered Head Together adalah agar pola interaksi antar siswa dan penguasaan akademik siswa dapat meningkat. Melalui kerjasama kelompok, siswa dapat saling membagikan ide atau pengetahuan dan meningkatkan kerjasama antar siswa dalam mempertimbangkan jawaban yang paling tepat (SY, dkk., 2016:1994). Penggunaan model pembelajaran kooperatif dengan tipe Numbered Head Together (NHT) ini dikuatkan oleh adanya fakta di lapangan berupa penelitian-penelitian terdahulu yang menunjukkan bahwa pengaruh model pembelajaran kooperatif Numbered Head Together memberikan pengaruh positif 
terhadap hasil belajar matematika dibandingkan dengan model pembelajaran konvensional (Santiana, dkk., 2014:1), berpengaruh positif terhadap hasil belajar matematika di Sekolah Dasar (Mulyawati, 2012:53), serta dapat meningkatkan kerjasama kelompok dan meningkatkan kompetensi siswa dalam membaca komprehensif (Maman and Rajab, 2016:179).

Model pembelajaran kooperatif dengan tipe Numbered Head Together (NHT) ini termasuk model pembelajaran kooperatif yang menarik karena memiliki kelebihan antara lain: (1) mampu meningkatkan kinerja siswa dalam tugas-tugas akademik, (2) siswa mampu menerima teman-temannya yang mempunyai berbagai latar belakang, dan (3) siswa dapat mengembangkan keterampilan sosial. Keterampilan yang dimaksud antara lain berbagi tugas, aktif bertanya, menghargai pendapat orang lain, mau menjelaskan ide atau pendapat, dan bekerjasama dalam kelompok (Nurhadi, dkk., 2004:67).

Berdasarkan latar belakang yang telah dijabarkan di atas, maka penelitian ini bertujuan untuk mengetahui pengaruh model pembelajaran Numbered Head Together (NHT) terhadap hasil belajar matematika siswa kelas V SD Negeri 2 Sumberejo Kabupaten Malang.

\section{METODE}

Penelitian ini merupakan penelitian kuasi eksperimen dengan menggunakan desain Nonequivalent Control Group Design. Adapun desain penelitian tertera pada tabel di bawah ini.

Tabel 1. Desain penelitian

\begin{tabular}{cccc}
\hline Kelas & Pretes & Perlakuan & Postes \\
\hline Eksperimen & $\mathrm{O}_{1}$ & $\mathrm{X}$ & $\mathrm{O}_{2}$ \\
Kontrol & $\mathrm{O}_{3}$ & & $\mathrm{O}_{4}$ \\
\hline
\end{tabular}

Keterangan:

$\mathrm{O}_{1} \quad$ : Pretes pada kelas eksperimen

$\mathrm{O}_{2} \quad$ : Postes pada kelas eksperimen

$\mathrm{O}_{3} \quad$ : Pretes pada kelas kontrol

$\mathrm{O}_{4} \quad$ : Postes pada kelas kontrol

$\mathrm{X} \quad$ : Perlakuan pada kelas eksperimen dengan penerapan model pembelajaran Numbered Head together (NHT)

Populasi dan sampel penelitian adalah 40 siswa-siswi kelas V SDN 2 Sumberejo Kabupaten Malang. Teknik pengambilan data pada penelitian ini menggunakan instrumen perangkat pembelajaran dan instrumen untuk mengukur variabel penelitian. Instrumen perangkat pembelajaran meliputi rencana pelaksanaan pembelajaran (RPP) dan lembar kerja siswa (LKS) sedangkan instumen untuk mengukur variabel penelitan adalah lima tes uraian yang valid dan reliabel untuk mengukur nilai pretes dan postes hasil belajar matematika pada masing-masing kelas kontrol dan kelas eksperimen, angket pembelajaran untuk mengetahui respon siswa terhadap penerapan model pembelajaran NHT, dan dokumentasi yang berupa fotofoto kegiatan pembelajaran di kelas. Sebelum data dianalisis dengan uji hipotesis, 
data harus memenuhi normalitas dan homogenitas data. Data yang dianalisis adalah data postes kelas kontrol dan data postes kelas eksperimen. Data tersebut dianalisis dengan menggunakan program IBM SPSS 22 dengan metode Independent Sample $t$ Test.

\section{HASIL DAN PEMBAHASAN}

Kondisi kognitif awal siswa berdasarkan nilai pretes masing-masing kelas menjadi langkah awal untuk menentukan bahwa kedua kelas tidak memiliki perbedaan yang signifikan. Penerapan model pembelajaran NHT dan model pembelajaran konvensional dilaksanakan sesuai dengan sintaks masing-masing model pembelajaran yang tertulis pada rencana pelaksanaan pembelajaran. Setelah pembelajaran berakhir, maka kedua kelas diberikan postes. Hasil pretes dan postes pada masing-masing kelas kontrol dan kelas eksperimen tertera pada tabel berikut.

Tabel 2. Nilai pretes dan postes

\begin{tabular}{lccc}
\hline \multicolumn{1}{c}{ Kelas } & $\mathrm{N}$ & $\begin{array}{c}\text { Rata-rata } \\
\text { Pretes }\end{array}$ & $\begin{array}{c}\text { Rata-rata } \\
\text { Postes }\end{array}$ \\
\hline Kontrol & 20 & 33,7 & 53,6 \\
Eksperimen & 20 & 33,25 & 63,8 \\
\hline
\end{tabular}

Sebelum dilakukan uji hipotesis, masing-masing nilai pretes dan postes kedua kelas diuji normalitas dan homogenitas data terlebih dahulu.

Tabel 3. Hasil uji normalitas

\begin{tabular}{llcccc}
\hline \multicolumn{1}{c}{ Nilai } & \multicolumn{1}{c}{ Kelas } & $\mathrm{L}_{0}$ & $\mathrm{~L}_{\mathrm{t}}$ & $\begin{array}{r}\text { Hubungan } \\
\mathrm{L}_{0} \text { dan } \mathrm{L}_{\mathrm{t}}\end{array}$ & Kesimpulan \\
\hline Pretes & Kontrol & 0,159 & 0,190 & $\mathrm{~L}_{0}<\mathrm{L}_{\mathrm{t}}$ & Normal \\
& Eksperimen & 0,179 & 0,190 & $\mathrm{~L}_{0}<\mathrm{L}_{\mathrm{t}}$ & Normal \\
\hline Postes & Kontrol & 0,144 & 0,190 & $\mathrm{~L}_{0}<\mathrm{L}_{\mathrm{t}}$ & Normal \\
& Eksperimen & 0,1703 & 0,190 & $\mathrm{~L}_{0}<\mathrm{L}_{\mathrm{t}}$ & Normal \\
\hline
\end{tabular}

Hasil uji normalitas menunjukkan bahwa data pretes untuk kelas eksperimen dan kontrol berdistribusi normal, begitu juga data postes untuk kelas eksperimen dan kontrol berdistribusi normal juga. Selanjutnya dilakukan uji homogenitas, dengan hasil sebagai berikut.

Tabel 4. Hasil uji homogenitas

\begin{tabular}{lcccl}
\hline Nilai & $\mathrm{F}_{0}$ & $\mathrm{~F}_{\mathrm{t}}$ & $\begin{array}{c}\text { Hubungan } \\
\mathrm{F}_{0} \text { dan } \mathrm{F}_{\mathrm{t}}\end{array}$ & Kesimpulan \\
\hline Pretes & 1,037 & 2,17 & $\mathrm{~F}_{0}<\mathrm{F}_{\mathrm{t}}$ & Homogen \\
Postes & 1,195 & 2,17 & $\mathrm{~F}_{0}<\mathrm{F}_{\mathrm{t}}$ & Homogen \\
\hline
\end{tabular}


Berdasarkan uji homogenitas menunjukkan bahwa varian nilai pretes kelas kontrol dan kelas ekperimen adalah homogen. Juga varian nilai postes kelas kontrol dan kelas ekperimen adalah homogen. Selanjutnya dilakukan uji hipotesis, hasilnya sebagai berikut.

Tabel 5. Hasil uji independent sample t test

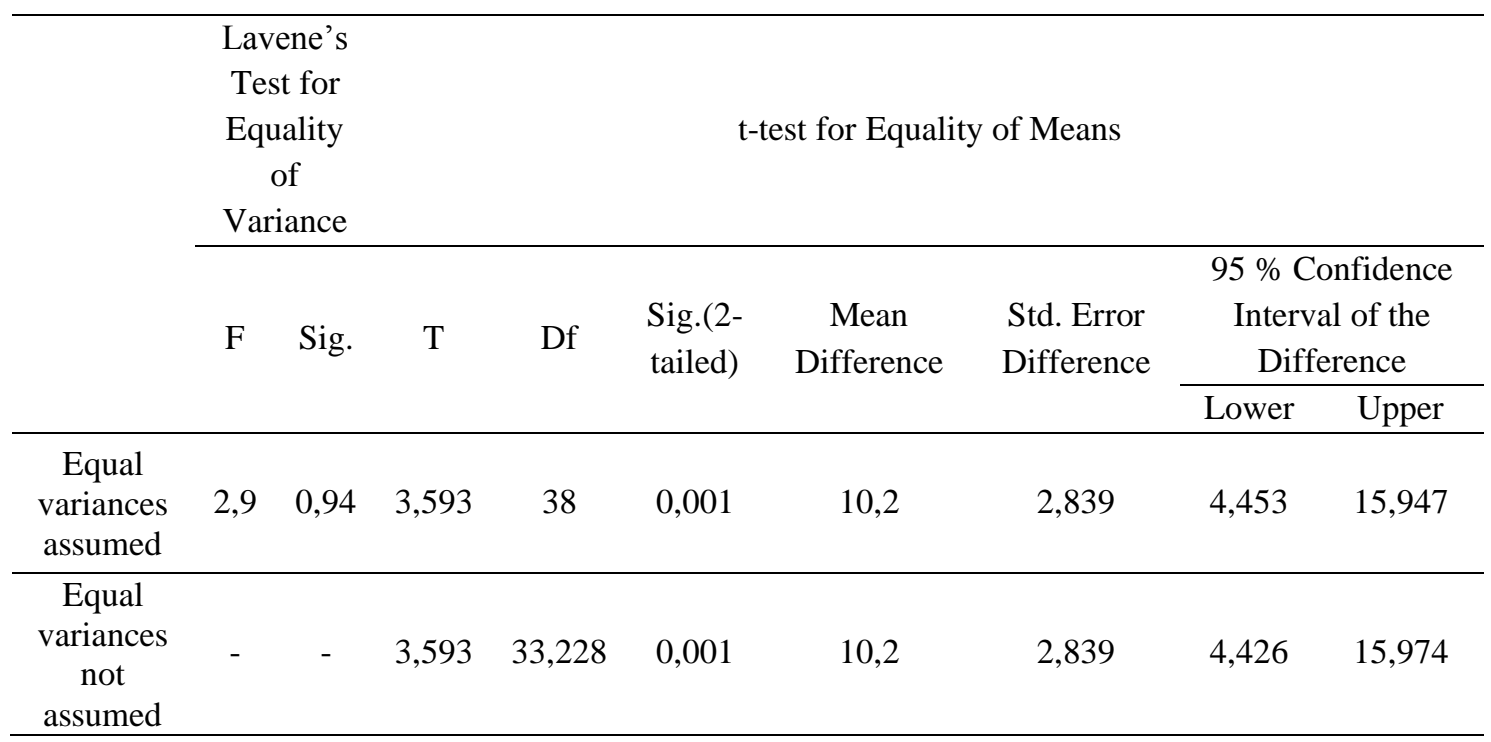

Hasil uji Independent Sample $t$ Test pada tabel 5 menunjukkan bahwa kedua kelas memiliki perbedaan secara signifikan. Hal ini dilihat pada nilai $\mathrm{t}_{\text {hitung }}$ atau $\mathrm{t}_{0}=$ 3,953 dan nilai $t_{\text {tabel }}(\alpha=0.05, \mathrm{~N}=40)=2,021$. Karena $t_{\text {hitung }}$ atau $\mathrm{t}_{0}>\mathrm{t}_{\text {tabel }}$ maka $\mathrm{H}_{0}$ ditolak dan $\mathrm{H}_{1}$ diterima. Artinya terdapat pengaruh yang signifikan antara model pembelajaran NHT terhadap hasil belajar matematika siswa kelas V SD.

Hal ini juga sejalan dengan hasil angket yang telah diberikan kepada 20 responden siswa yang ada di kelas eksperimen yang diterapkan model NHT yang menunjukkan bahwa siswa setuju dengan adanya penerapan model NHT karena dapat meningkatkan nilai hasil belajar dan kemampuan sosial di kelas mereka.

Hasil penelitian ini sejalan dengan penelitian terdahulu, yakni penelitian Santiana, dkk (2014) yang menunjukkan bahwa penerapan model pembelajaran kooperatif Numbered Head Together (NHT) memberikan pengaruh positif terhadap hasil belajar matematika pada siswa kelas V SD Negeri Alasangker. Mulyawati (2012) juga menunjukkan bahwa model pembelajaran kooperatif Numbered Head Together (NHT) berpengaruh terhadap hasil belajar matematika siswa kelas IV SD Imbas Gugus Hasanudin Salatiga pada semester genap tahun 2011/2012. Sama halnya dengan Maman dan Rajab (2016) dengan penelitiannya yang berjudul The Implementation of Cooperatif Learning Model Numbered Head Together (NHT) in Improving the Student's Ability in Reading Comprehension menunjukkan bahwa 84 persen siswa memiliki perubahan yang baik dalam membaca komprehensif setelah mengikuti pembelajaran dengan model NHT.

Setelah postes, diambil hasil postes dari 3 siswa yang memiliki kemampuan pengetahuan rendah, sedang, dan berkemampuan tinggi pada masing-masing kelas. Misalnya pembahasan pada soal nomor 5 berikut: 
5. Perhatikan gambar dibawah ini!

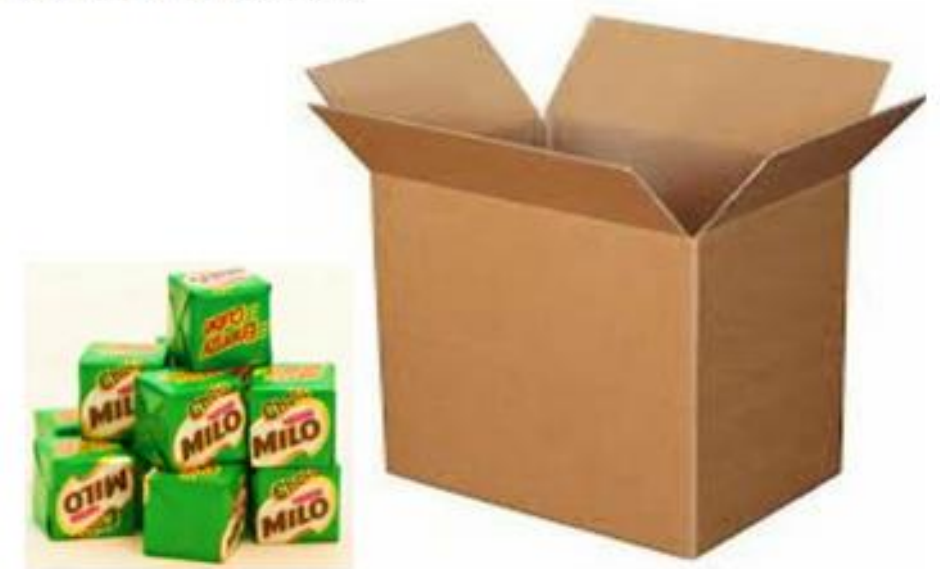

Permen coklat berbentuk kubus dengan panjang sisirya $2 \mathrm{~cm}$ akan dimasukkan ke dalam kardus yang berukuran $8 \mathrm{~cm} \times 4 \mathrm{~cm} \times 8 \mathrm{~cm}$. Berapakah jumlah permen yang dibutuhkan untuk mengisi kardus tersebut hingga penuh?

Gambar 1. Soal uraian nomor 5

Berdasarkan hasil kerja siswa, jawaban 3 siswa dari kelas ekperimen dengan menggunakan model pembelajaran NHT menjawab lebih tepat dari pada jawaban dari 3 siswa kelas kontrol yang menggunakan model pembelajaran konvensional. Hal ini terlihat dari hasil kerja siswa pada soal nomor 5 tersebut.

a. Siswa dengan kemampuan pengetahuan rendah

Siswa kelas kontrol dengan kemampuan rendah menjawab soal nomor 5 seperti pada gambar berikut.

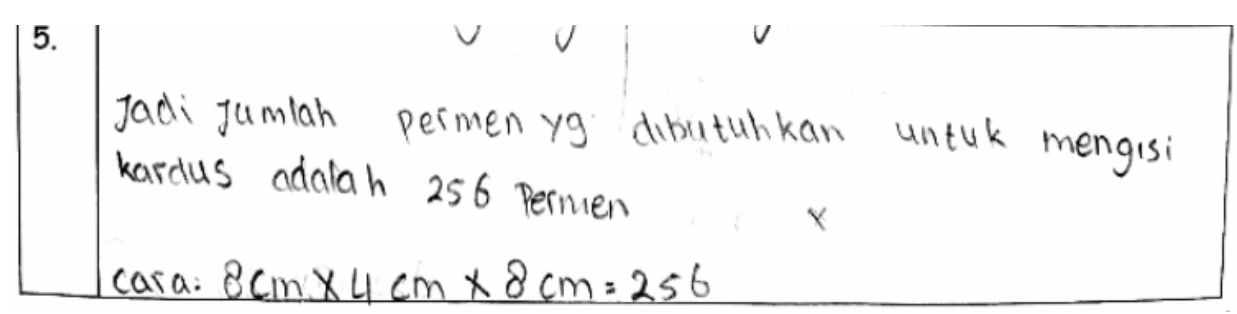

Gambar 2. Hasil kerja siswa berkemampuan rendah kelas kontrol

Siswa ini menjawab soal nomor 5 dengan tidak menuliskan apa yang diketahui dan apa yang ditanyakan dalam soal. Hal ini menunjukkan bahwa siswa tidak melaksanakan fase penerimaan informasi dengan baik (Syah, 2010:111). Cara siswa dalam menjawab soal pun tidak sesuai dengan prosedur. Sehingga ia menyelesaikan soal dengan tidak lengkap, yaitu hanya menjawab pada tahap mencari volume kardus yaitu bervolume $256 \mathrm{~cm}^{3}$. Namun ia menerjemahkan angka dari volume kardus tersebut sebagai jumlah permen yang ditanyakan dalam soal padahal hal itu bukanlah jawaban yang diinginkan pada soal ini. Sehingga hasil akhirnya salah. Hal ini menunjukkan bahwa siswa juga mengalami kesalahan pada fase transformasi dan tahap evaluasi (Syah, 2010:111). Selain itu siswa juga belum bisa memecahkan masalah dengan 
benar karena siswa belum bisa berpikir abstrak dan sistematis secara rasional dan tuntas (Syah, 2010:120).

Lain halnya dengan hasil kerja siswa berkemampuan rendah pada kelas eksperimen yang ditunjukkan pada gambar berikut.

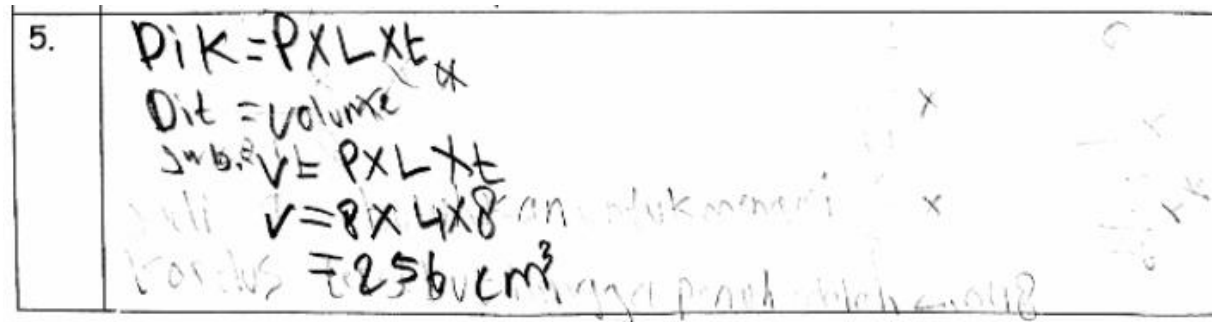

Gambar 3. Hasil kerja siswa berkemampuan rendah kelas eksperimen

Siswa ini mengerjakan soal dengan menuliskan rumus volume balok dan kurang memahami apa yang ditanyakan pada soal nomor 5 ini. Ia menganggap bahwa yang ditanyakan dalam soal adalah berapa volume kardus tersebut, padahal yang ditanyakan adalah jumlah permen yang ada dalam kardus tersebut. Ia menghitung volume kardus dengan tepat. Hal ini sebenarnya sudah mendekati proses pencarian jumlah permen yang ada dalam kardus, namun ia hanya berhenti pada tahap mencari volume kardus. Hal ini menunjukkan bahwa siswa sudah melewati fase penerimaan informasi namun penerimaan informasi tersebut belum memuat informasi lengkap dari soal yang dikerjakan. Selain itu siswa juga belum bisa mentransformasi dan mengevaluasi soal dengan benar (Syah, 2010:111). Pemikiran abstrak siswa pun masih lemah, hal ini terlihat pada hasil penulisan variabel yang diketahui dan apa yang ditanyakan tidak tertulis dengan benar (Syah, 2010:120). Hal ini menyebabkan jawaban siswa menjadi tidak tepat karena ia belum bisa memecahkan masalah secara menyeluruh (Syah, 2010:121).

b. Siswa dengan kemampuan pengetahuan sedang

Hasil kerja siswa berkemampuan sedang pada kelas kontrol menjawab soal nomor 5 dengan jawaban seperti pada gambar berikut.

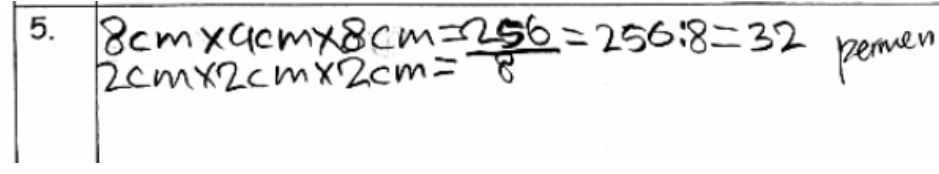

Gambar 4. Hasil kerja siswa berkemampuan sedang kelas kontrol

Hasil kerja di atas menunjukkan bahwa siswa tidak menuliskan apa yang diketahui dan apa yang ditanyakan pada soal. Namun siswa memahami soal dengan benar sehingga ia menjawab soal dengan benar pula yaitu menjawab jumlah permen sebanyak 32 buah permen. Hal ini menunjukkan bahwa siswa sudah mampu mentransformasi soal dan mampu berpikir rasional dalam memecahkan masalah (Syah, 2010:118). Meskipun jawaban ini jika dirinci di awal proses penghitungan belum sepenuhnya benar karena penulisan satuan pada volume kardus dan satuan volume dari permen masih salah karena tidak dituliskan dengan benar, hal ini menunjukkan bahwa siswa tidak memahami soal dengan sempurna. 
Hasil kerja siswa yang memiliki kemampuan sedang pada kelas eksperimen ditunjukkan pada gambar berikut ini.

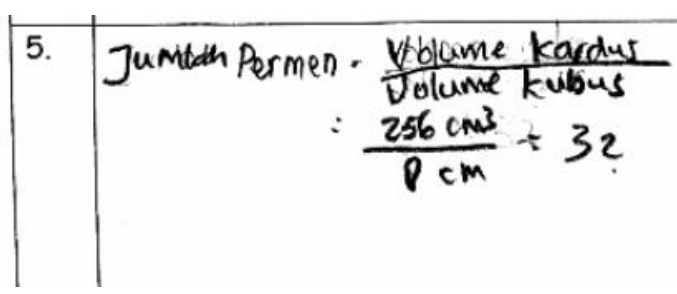

Gambar 5. Hasil kerja siswa berkemampuan sedang kelas eksperimen

Hasil kerja siswa kelas eksperimen yang memiliki kemampuan sedang menunjukkan bahwa siswa paham dengan apa yang diketahui dan apa yang ditanyakan dalam soal nomor 5 ini. Hal ini menunjukkan bahwa siswa memahami soal dengan baik namun pengerjaan soal dilakukan secara tidak sistematis (Syah, 2010:121). Ia tidak menuliskan variable-variabel yang diketahui dalam soal nomor 5 ini. Satuan volume sudah dituliskan dengan benar yaitu satuan dari volume kardus dan sebagian lagi ditulis secara tidak tepat yaitu satuan dari volume permen. Ia memahami bahwa untuk mencari jumlah permen yang dapat mengisi kardus sampai penuh tersebut yaitu dengan membagi volume kardus dengan volume satu permen. Hasil dari jawaban siswa ini benar yaitu 32. Meskipun satuan permen tidak dituliskan pada jawaban. Sehingga ia mengalami kesalahan sebagian dalam mengevaluasi soal (Syah, 2010:111).

c. Siswa dengan kemampuan pengetahuan tinggi

Hasil kerja siswa kelas kontrol yang memiliki kemampuan tinggi dapat dilihat pada gambar berikut.

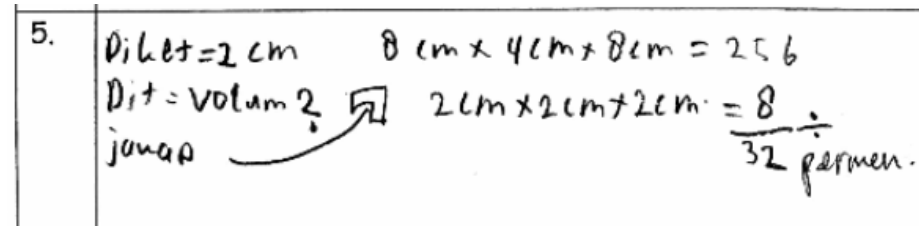

Gambar 6. Hasil kerja siswa berkemampuan tinggi kelas kontrol

Hasil kerja siswa yang berkemampuan tinggi pada kelas kontrol ini menunjukkan bahwa siswa sudah menuliskan variabel apa saja yang diketahui pada soal nomor 5 namun belum lengkap. Hal ini menunjukkan bahwa siswa sudah memahami soal dengan baik namun proses transformasi masih belum dilakukan dengan sempurna (Syah, 2010:111). Namun proses penghitungan untuk mencari volume kardus dan volume permen sudah benar, hanya saja satuan dari volume kedua benda tersebut tidak ditulis. Ia memahami bahwa untuk mencari berapa jumlah permen yang dapat dimuat dalam kardus adalah dengan membagi volume kardus dengan volume permen yaitu 32 permen. Hal ini menunjukkan bahwa siswa sudah mulai berpikir kristis dalam menyelesaikan masalah berdasarkan apa yang diketahui pada soal (Syah, 2010:120). 
Hasil kerja siswa yang memiliki kemampuan tinggi pada kelas eksperimen ditunjukkan pada gambar berikut ini.

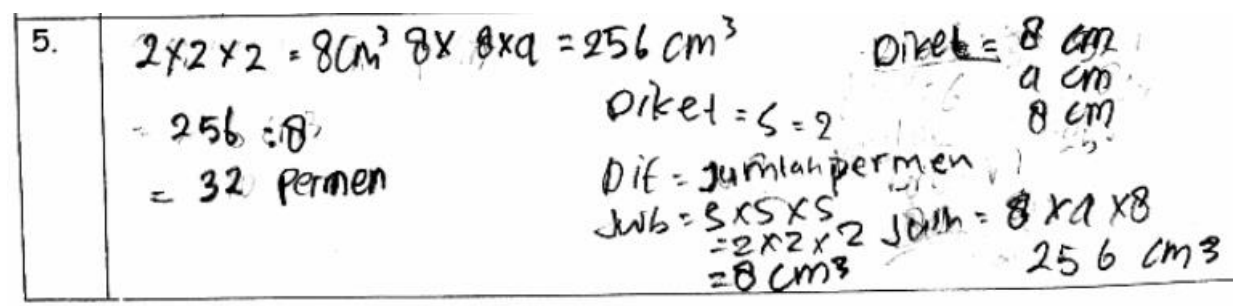

Gambar 7. Hasil kerja siswa berkemampuan tinggi kelas eksperimen

Berdasarkan gambar di atas maka dapat dijelaskan bahwa secara keseluruhan, hasil kerja siswa berkemampuan tinggi ini mampu menuliskan apa yang diketahui, apa yang ditanyakan, serta menjawab soal dengan benar. Sehingga siswa ini mampu menyelesaikan masalah pada soal nomor 5 ini sesuai dengan urutan langkah-langkah penyelesaian soal. Hal ini menunjukkan bahwa siswa telah melewati fase penerimaan informasi, fase transformasi, serta fase evaluasi dengan baik (Syah, 2010:120). Pada proses penghitungan volume sudah menyertakan satuan volume dengan benar yaitu volume kardus $256 \mathrm{~cm}^{3}$ dan volume satu permen $8 \mathrm{~cm}^{3}$. Cara mencari berapa jumlah permen yang dapat dimuat pada kardus juga telah dipahami dengan baik oleh siswa, yaitu dengan cara membagi volume kardus dengan volume satu permen. Hasil penghitungan siswa ini juga benar yaitu jumlah permen yang dapat dimuat adalah sebanyak 32 permen. Hal ini menunjukkan bahwa siswa mampu berpikir kritis, sistematis, dan menyeluruh sehingga ia bisa menjawab soal dengan benar (Syah, 2010:121). Selain itu siswa juga memiliki daya ingat yang tinggi dalam memahami skema yang telah dipelajari dan mampu melaksanakan prosedural dengan benar (Slavin, 2008:228).

Perbandingan hasil kerja siswa pada soal nomor 5 tersebut memang jelas terdapat perbedaan, siswa kelas eksperimen memiliki kemampuan yang lebih baik setelah diterapkan model pembelajaran NHT daripada kemampuan siswa yang tetap menggunakan model pembelajaran konvensional. Hal ini memang diketahui bahwa model pembelajaran NHT memiliki keunggulan dimana siswa dapat berinteraksi melalui diskusi kelompok dalam menyelesaikan masalah yang dihadapi, kerjasama dalam kelompok kooperatif memungkinkan ilmu pengetahuan yang terbentuk menjadi lebih luas, siswa dapat mengembangkan bakat bertanya, berdiskusi, dan kemampuan kepemimpinan. Adapun salah satu yang menjadi keunikan dalam model pembelajaran NHT adalah setiap siswa dalam kelompok memiliki nomor urut atau nomor kepala dimana ketika nomor-nomor tersebut dipanggil oleh guru untuk menjawab sebuah pertanyaan, maka siswa harus siap menjawab dengan jawaban mereka masing-masing (Lestari, 2015:4). Sehingga siswa lebih antusias dalam bekerja sama dalam kelompok untuk menyiapkan jawaban yang paling tepat. 


\section{SIMPULAN DAN SARAN}

Berdasarkan hasil penelitian dan pembahasan, dapat disimpulkan bahwa terdapat pengaruh yang signifikan model pembelajaran kooperatif Numbered Head Together (NHT) terhadap hasil belajar matematika siswa kelas V SD. Pengaruh ini terlihat pada perbedaan nilai postes antara kelas kontrol dan kelas eksperimen yang telah diuji secara statistik bahwa $t_{\text {hitung }}>t_{\text {tabel. }}$. Pengaruh tersebut juga terlihat pada selisih nilai rata-rata kedua kelas sebesar 10,2 dimana kelas kontrol memiliki nilai rata-rata 53,6 sedangkan kelas eksperimen memiliki nilai rata-rata 63,8. Hasil angket menunjukkan bahwa dari total 20 responden, rata-rata responden memberikan nilai 62,8 pada setiap item yang diajukan. Nilai ini menunjukkan siswa setuju terhadap penerapan model pembelajaran Numbered Head Together (NHT) di kelas mereka.

Selanjutnya dari penelitian ini dapat disarankan agar: (1) model pembelajaran Numbered Head Together (NHT) dapat diterapkan oleh pendidik jenjang sekolah dasar karena dapat meningkatkan hasil belajar kognitif dan sosial siswa, (2) siswa diharapkan untuk bekerjasama dalam kelompok tanpa melihat perbedaan latar belakang antar kelompok, sehingga minat belajar, pemahaman, dan hasil belajar siswa dapat meningkat, (3) Kepala Sekolah SD diharapkan dapat membuat kebijakan penggunaan model pembelajaran NHT ini agar dapat digunakan dalam KBM matematika di SD. Hal ini mengingat penerapan Kurikulum K13 yang menuntut siswa untuk aktif dalam setiap pembelajaran di kelas.

\section{DAFTAR PUSTAKA}

Awang, H., Samad, A. N., Faiz, M. N., Roddin, R., and Kankia, J. 2017. Relations Between the Learning Styles Preferences and Academic Achievment. International Research and Innovation Summit, Vol 1(1) : 1-5.

Gustadevi, A. S., Ngadiso, and Asib, A. 2012. Improving Student's Reading Skill Through Numbered Head Together Technique. Neliti, Vol.1(18) : 191-203.

Lestari, K. C. 2015. Penerapan Metode Numbered Heads Together (NHT) untuk Meningkatkan Keaktifan dan Hasil Belajar Siswa terhadap Mata Pelajaran Mulok Produktif Membuat Jajanan Tradisional Kelas X TPHP II di SMKN 1 Pandak Tahun Ajaran 2014/2015. Skripsi tidak dipublikasikan. Yogyakarta: Universitas Negeri Yogyakarta..

Maman, M., and Rajab, A. A. 2016. The Implementation of Cooperative Learning Model Numbered Heads Together (NHT) in Improving the Student Ability in Reading Comprehension. International Journal of Evaluation and Research in Education (IJERE), Vol. 5(2), 174-180.

Mulyawati, V. 2012. Pengaruh Model pembelajaran Kooperatif Tipe Numbered Heads Together (NHT) terhadap Hasil Belajar Matematika Kelas IV di SD Imbas Gugus Hasanudin Salatiga Semester Genap Tahun 2011/2012. Skripsi tidak dipublikasikan. Salatiga: Universitas Kristen Satya Wacana.

Nurhadi, Yasin, B., dan Senduk, A. G. 2004. Pembelajaran Kontekstual dan Penerapannya (Contextual Teaching and learning) dalam KBK. Malang: Universitas Negeri Malang.

Peraturan Pemerintah No. 19 Tahun 2005 tentang Standar Nasional Pendidikan. 2005. Jakarta: Kementerian Pendidikan dan Kebudayaan.

Ruliani, B., dan Pramukantoro, J. 2014. Hubungan antara Model Pembelajaran dengan Hasil Belajar pada Mata Pelajaran Teknik Elektronika Siswa Kelas X 
EI SMKN 1 Jetis Mojokerto. Jurnal Pendidikan Teknik Elektro, Vol. 03(01) : 141-147.

Santiana, M., Ni, N. G., dan Dewa , N. S. 2014. Pengaruh Model Pembelajaran Kooperatif Tipe Numbered Heads Together (NHT) Terhadap Hasil Belajar Matematika Siswa Kelas V Sekolah Dasar di Desa Alasangker Odel. e-Journal MIMBAR PGSD Universitas Pendidikan Ganesha, Vol. 2(1) : 1-10.

Slavin, R. E. 2008. Psikologi Pendidikan Teori dan Praktik. Jakarta: PT. Indeks.

SY, N., Corebima, A. D., dan Susilo, H. 2016. Pengaruh Strategi Pembelajaran Numbered Heads Together (NHT) terhadap Hasil Belajar Siswa SMA Negeri 1 Muara Badak. Teori, Penelitian, dan Pengembangan, Vol. 1(10) : 1993-1998.

Syah, M. 2010. Psikologi Pendidikan dengan Pendekatan Baru. Bandung: PT. Remaja Rosdakarya Offset. 